\title{
Review of the generic level classification of the New World Ascalaphidae (Neuroptera)
}

\author{
Norman D. Penny $\left({ }^{*}\right)$
}

\begin{abstract}
The higher classification of New World Ascalaphidae is modified to reflect new information and many changes proposed in various papers over the past 70 years. The attempt has been made to retain as much as possible the traditional conceptual structure, whenever warranted. Keys and synoptic descriptions are provided for American subfamilies, tribes and genera. One new synonomy (Episperches Gerstaecker = Amoea Lefèbvre), one new name (Ascalobyas for Byas Rambur) and one new genus (Neohaploglenius) are proposed.
\end{abstract}

\section{INTRODUCTION}

Ascalaphidae, or owlflies, are large, sometimes showy insects that occasionally were even placed together with butterflies in the genus Papilio. Some European species are day-flying, and some have boldly patterned wings. However, trying to identify owlflies is difficult because of the many nomenclatural changes in scattered literature. Little progress has been made by specialists during the past 50 years to summarize these modifications into a form that other specialists can use. The purpose of this paper is to provide necessary nomenclature, illustrations, keys and descriptions for adequate determination of these neuropterans to generic level.

Ascalaphidae are often common, yet little understood Neuroptera in the New World. They closely resemble Odonata, to the point that the genus of dragonfly model can sometimes be identified. Ascalaphidae are aerial predators, often occupying an ecological niche very similar to Odonata. Most adult feeding activity seems to be confined to dusk (and perhaps dawn), thus allowing Odonata reign of the skies during the daytime and bats at night. Such fortuitous dividing of feeding time is probably a survival mechanism for Ascalaphi- dae, as both these other groups are probably owifly predators, and Odonata have actually been seen to capture Ascalaphidae in flight, when flushed from their resting place. The wings at rest are folded over the body and long, knobbed antennae are placed in front of the head and parallel with the substrate, thus giving the body a long, very narrow form (Ascalaphinae), or wings are held out to the sides, as in Odonata (Haplogleninae). During the daytime, adult owlflies normally rest on grass stems; small, dead tree branches, etc.; and when disturbed fly low and quickly to another resting place. Larvae rest on plant foliage or sand with enlarged mandibles open, waiting for soft-bodied insect prey, or actively pursuing them.

There are two interesting geographical anomalies in the distribution of Ascalaphidae. This family is much more common and diverse in south temperate America than in north temperate America. Argentina has 19 species and subspecies in eight genera, while the United States has only 10 species and subspecies in three genera. The second anomaly is that Chile has no owlflies. Although the country is quite diverse in habitats, the Andean barrier appears to have prevented the introduction of Ascalaphidae.

\section{Systematics}

The first and only good, modern treatment of the Ascalaphidae was written by Weele (1908). A later monograph on South American Ascalaphidae by Navás (1913) used the same classification system as Weele (except for placing Stilbopterygidae in Haplogleninae) and added a few more species, but lacked the detailed descriptions and illustrations of the

(*) - Instituto Nacional de Pesquisas da Amazônia, Manaus. 
earlier work. Since 1908 there has been no comprehensive treatment of Ascalaphidae for North or Central America.

The subfamily classification of Weele was based partly on the earlier work of MacLachlan (1871). Both used subfamily names which were not based on existing generic names, and until recently, subsequent authors followed this scheme. In conformity with Article 29 of the International Code of Zoological Nomenclature, subfamily names have been changed to conform to previously described, but seldom used, terminology.

\section{Family ASCALAPHIDAE Lefèbvre, 1842}

Ascalaphidae Lefèbvre, 1842, Guerin's Mag. Zool., 4: Table 92.

\section{Type Genus: Ascalaphus Fabricius}

The family Ascalaphidae can be characterized by: holometabolous insects of the neuropteran suborder Planipennia. Active terrestrial or arboreal larvae with long hollow mandibles used to suck body fluids from prey; dorsocaudal margin of head bilobed; prominent lateral projections on thoracic and abdominal segments. Adult antennae filiform, terminating in an oval or elliptical club. Eyes large, globose, either entire or divided. Thorax stout, pilose. Legs elongate, with five tarsal segments. Abdomen elongate, thin. Fore-and hindwings usually similar with dense network of crossveins.

\section{KEY TO SUBFAMILIES OF ASCALAPHIDAE}

1A. Eyes entire, not divided by transverse sulcus

(Fig. 2) ........... Haplogleniinae New.

1B. Eyes divided by transverse sulcus into two parts, superior and inferior, equal or unequal

(Fig. 1) ............ Ascalaphinae Lef.

Subfamily HAPLOGLENINAE Newman, 1853

Olophthme Lefèbvre, 1842, Guerin's Mag. Zool., 4: Table 92 (invalid, not based on existing genus).
Haploglenidae Newman, 1853, Zoologist, 11:

Holophthalmi MacLachlan, 1871, J. Linn. Soc. Lond., 11: 233 (invalid, not based on existing genus).

Holophthalminae Weele, 1908, Coll. Zool. Edm. Selys Longchamps, 8: 26 (invalid, not based on existing genus).

Verticillecerinae Orfila, 1949, Annuls Soc. cient. Argent., 148: 188 .

Ascaloptynginae MacLeod, 1970. Psyche, Camb., 77:

\section{Type Genus: Haploglenius Burmeister}

This subfamily is characterized by entire compound eyes; antennae short to long, but always longer than thorax; long, narrow wings: cubital fork of hindwings well developed.

Weele (1908) listed 19 genera and 45 species within the Haplogleniinae, of which 6 genera and 18 species were from the Western Hemisphere. Penny (1977) listed 5 genera and 26 species from Central and South America.

In his treatment or South American Ascalaphidae Navás (1913) further divided this subfamily into three tribes: Albardini, Eplsperchini and Neuroptyngini. The first of these tribes contains a single American species, now considered to be part of the family Stilbopterygidae. The second tribe contains the type genus of the subfamily, Haploglenius, and must take the name Haplogleniini. Banks (1915) pointed out that the type genus of Neuroptyngini, Neuroptyx McClendon, was a syno nym of Haploglenius, so that the third tribe takes the next available name, Verticillecerini Orfila. The tribes of Haplogleniinae can be separated using the following key.

\section{KEY TO AMERICAN TRIBES OF HAPLOGLENIINAE}

1A. Forewing with prominent axillary angle at base of anal margin (wing cells distal to axillary angle shorter than within angle) (Figs. 3, 6, 7)......Verticillecerini Orfila

1B. Forewing without prominent axillary angle at base of anal margin (wing cells distal of axillary angle equal to or longer than along basal curve)

(Fig. 4) ......... Haplogleniini Newman 


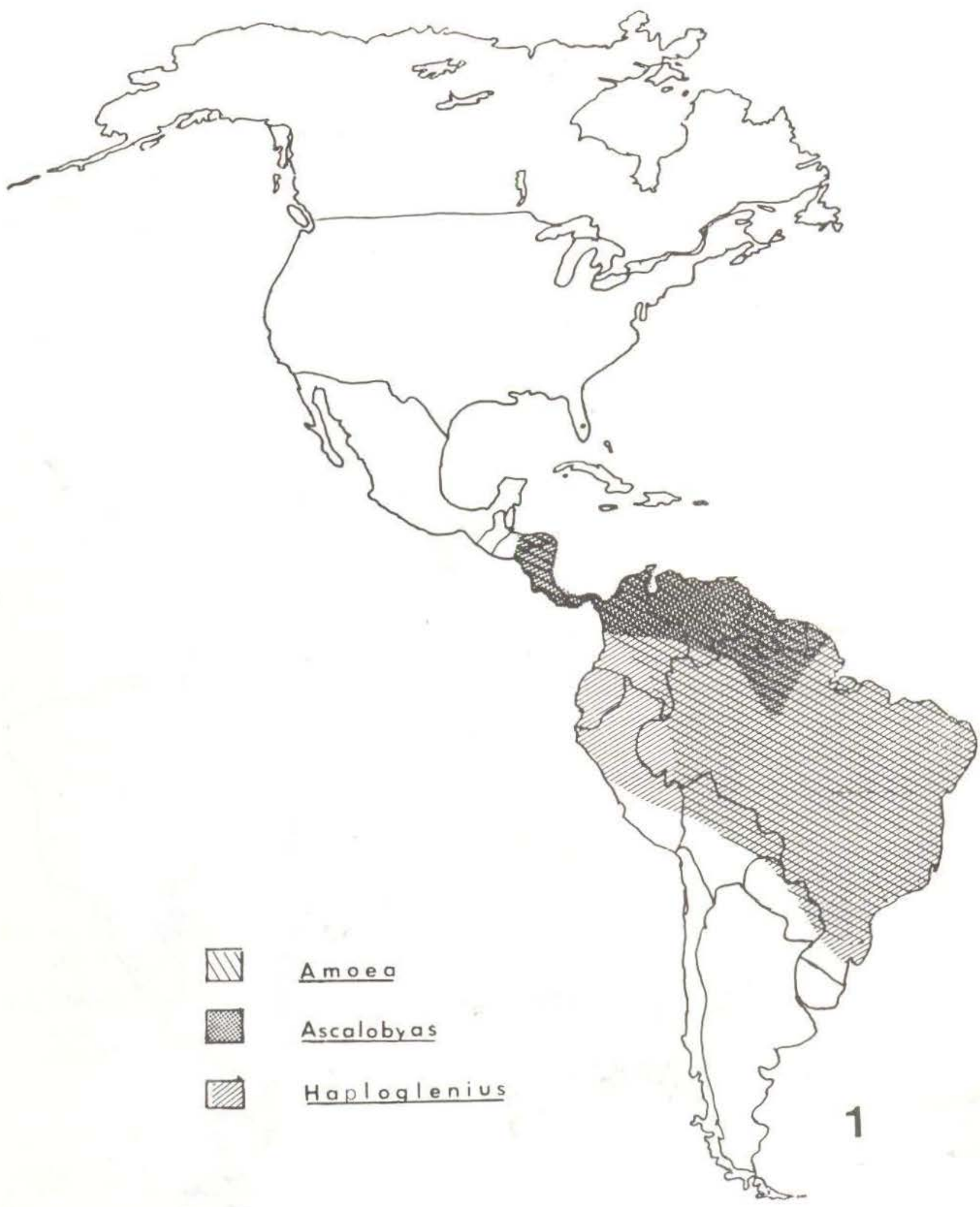

Map 1 - Known geographical distribution of the tribe Haplogleniini.

Review.. 


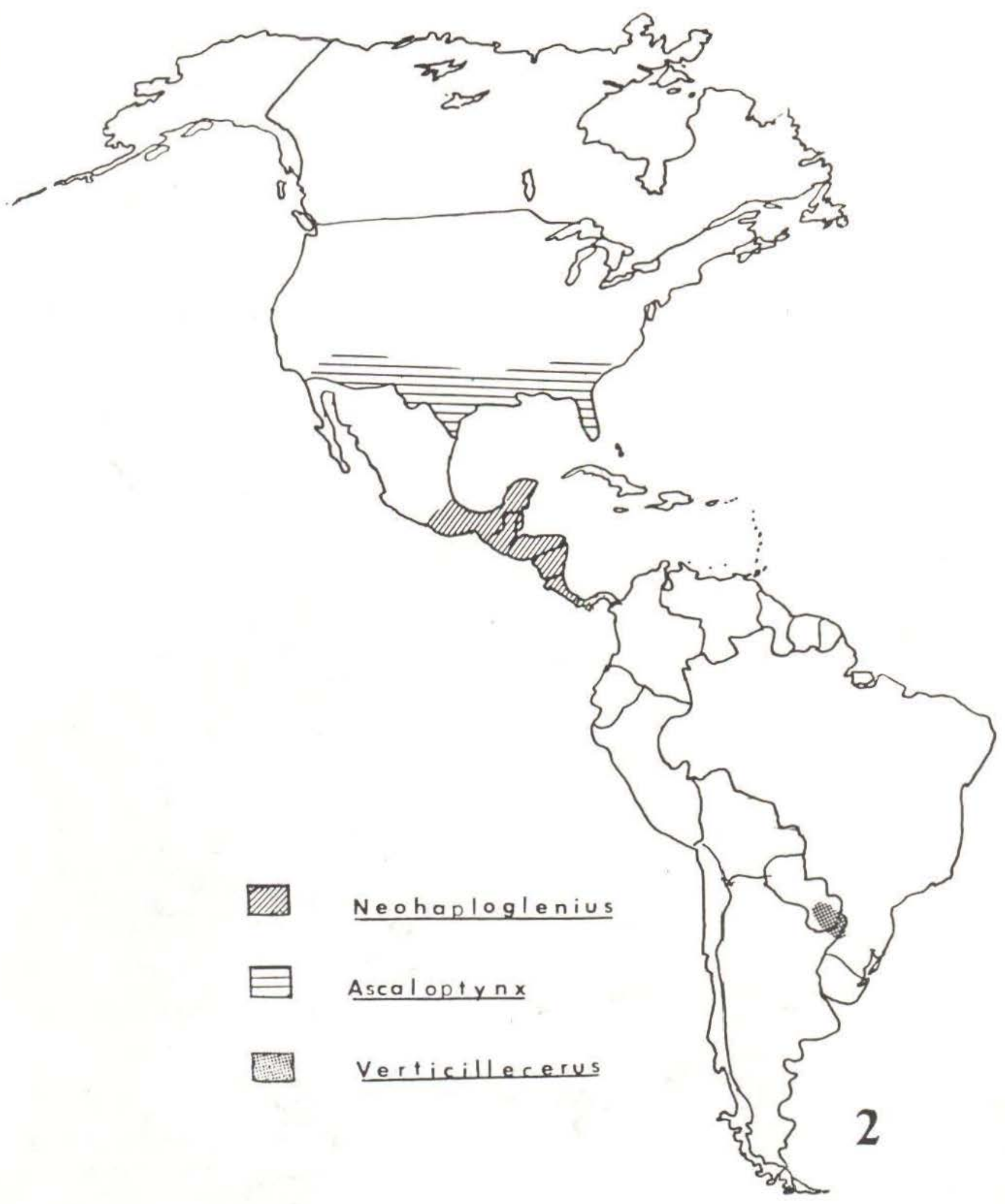

Map 2 - Known geographical distribution of the tribe Verticillecerini. 
Tribe HAPLOGLENIINI Newman, 1853

Haploglenini Newman, 1853, Zoologist, 11: Episperchini Navás, 1913, Broteria, 10: 206.

\section{Type Genus: Haploglenius Burmeister}

This tribe is characterized by long, narrow wings without an axillary angle of the forewing. There has been much confusion as to the generic, and even tribal classification, created from Weele's (1908) monograph. For example, within Weele's genus Haploglenius were species with very distinct axillary angles of the wings, others without. One of the key characters to generic identification was a darkened costal wing margin, but all shades can be found, from dark black to pale yellow to clear. Thus, the genera within this tribe have had to be recharacterized. In the present study, three genera of American Haploglenini are recognized: Amoea, Ascalobyas and Haploglenius.

\section{KEY TO GENERA OF HAPLOGLENIINI}

1A. Antennae longer than distance to second Rs fork of forewing

(Fig. 4) .................... 2

1B. Antennae shorter than distance to second Rs fork of forewing

(Fig. 5) ..........Ascalobyas new name

$2 A$. Hindwing with $2 A$ present, long

(Fig. 4) .........Haplo glenius Burmeister

$2 B$. Hindwing with $2 A$ absent or extremely short

(Fig. 3) ..............Amoea Lefèbvre

Genus Amoea Lefèbvre, 1842

(Fig. 2)

Amoea Lefèbvre, 1842, Guerin's Mag. Zool., 4: 6 .

Episperches Gerstaecker, 1893, Mitt. Vorpomm. und Rügen, 25: 98 (new synonomy).

Type Species: of Amoea is Haploglenius subcostatus Burmeister, now considered a synonym of Amoea immaculata Olivier, by mono- typy. Type species of Episperches is Epis perches vacuus (Gerstaecker) by present desig. nation.

The characters used to separate Amoea and Episperches have been the more rounded hindwing and in males the wider basal abdominal segments. These are both characters subject to much variation within both genera. For instance, the hindwing of Amoea immacu. lata (Olivier) appears to be wider than Episperches arenosus Walker, but narrower than Episperches impediens Walker. The width of the abdomen often depends on how the specimen dried, and present specimens of Episperches species are as narrow as Amoea. It being virtually impossible to separate the genera, the only reasonable solution seems to be synonomy.

Amoea is confined to South and Central America from Argentina north to Guatemala. Penny (1977) listed 11 valid species within the genera (Amoea and Episperches). There has not been a comprehensive treatment of the genera given since Weele (1908) and Navás (1913).

\section{Genus Ascalobyas new name (Fig. 5)}

Byas Rambur, 1842, Hist. nat. des Insectes Nèvroptères, p. 361. (preoccupied by Byas Dalman, 1820; and Byas Morris, 1837).

Type Species: Byas microcerus Rambur, by present designation.

This genus is easily separated from others of this tribe by shorter antennae. All known species have a dark costal margin of the wings.

Ascalobyas is presently known from two species ranging from northern Brazil to Panama.

Genus Haploglenius Burmeister, 1839 (Fig. 4)

Haploglenius Burmeister, 1839, Handbuch der Zool., p. 1000.

Review. . 


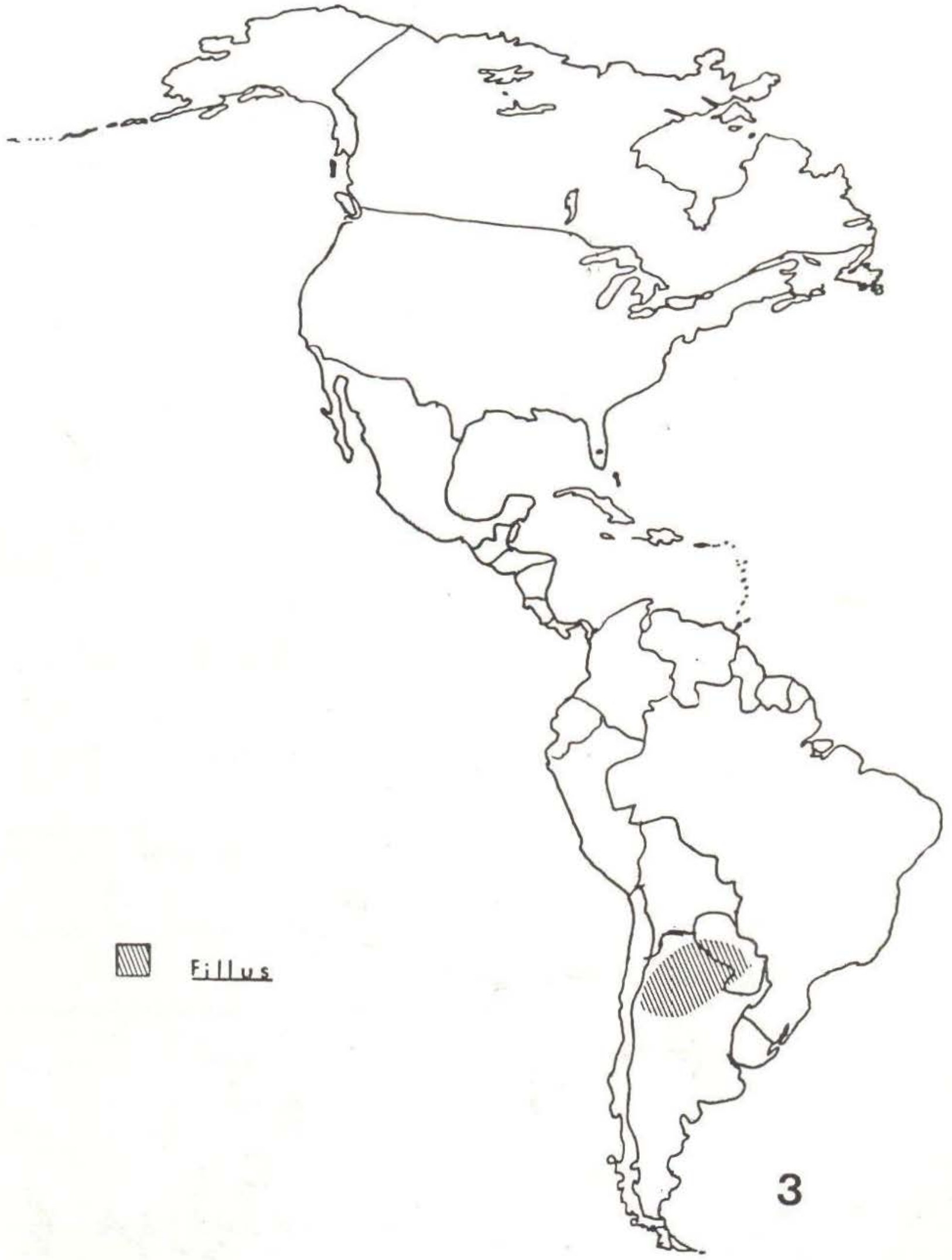

Map 3 - Known geographical distribution of the tribe Suhpalacsini in the New World. 


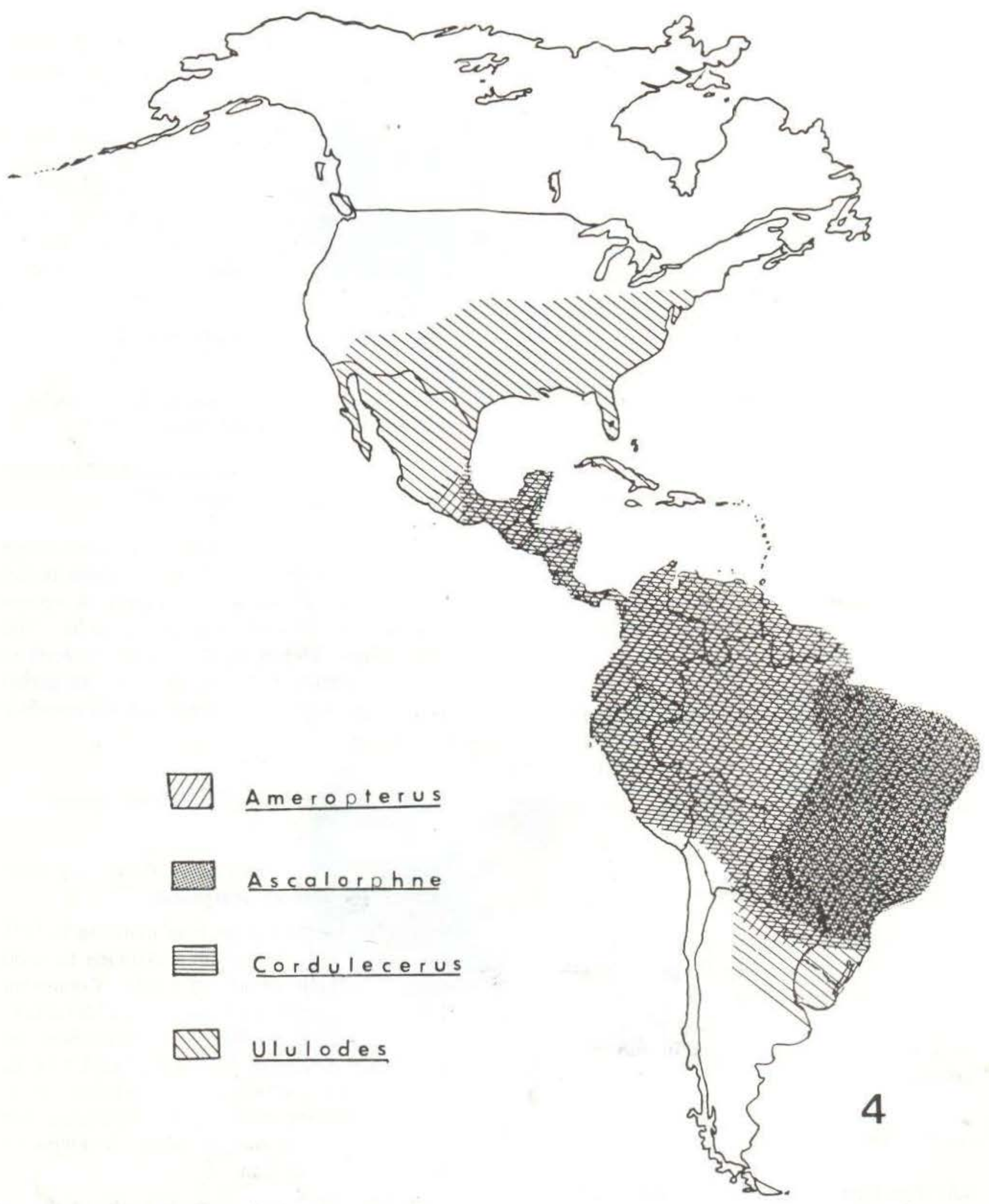

Map 4 - Known geographical distribution of the tribe Ululodini.

Revicw... 
Ptynx Lefebvre, 1842, Guerin's Mag. Zool., 4: 6 (preoccupied by Ptynx Moehring, 1758, and Ptynx Blyth. 1840)

Neuroptynx McClendon, 1906, Ent. News, 17: 172. (synonomized by Banks, 1915).

Type Species: Haploglenius costatus Burmeister.

Haploglenius is placed together with Amoea and Ascalobyas in the tribe Haplogleniini. Haploglenius has longer antennae than Ascalobyas, and one more anal vein of the hindwing than Amoea. Two species listed by Weele (1908), $H$. angulatus Gerstaecker and $H$. flavicornis MacLachlan, are herein transferred to a new genus, Neohaploglenius, in the tribe Verticillicerini. The costal margin of the wing is usually dark, but it can be very pale in some individuals, and in $\mathrm{H}$. bolivianus $\mathrm{Na}$ vás is completely clear. Navás (1928) listed distinguishing characters of the eight species known at the time. However, later addition of one species and present transfer of two others gives this genus seven known species ranging from Argentina north to Honduras.

Tribe VERTICILLICERINI Orfila, 1949

Neuroptyngini Navás, 1913, Broteria, 10: 212 (Type genus was synonomized by Banks, 1915)

Verticillicerini Orfila, 19.49. Annuls Soc. cient, argent., 148: 188

\section{Type Genus: Verticillicerus Weele.}

This tribe is characterized by long, narrow wings and a strongly differentiated axillary angle of the forewings. Verticillicerini presently includes three genera of New World owlflies, ranging from Argentina north to the southern United States.

\section{KEY TO GENERA OF VERTICILLICERINI}

1A. Basal part of antennae with whorls of long setae

(Fig. 6) ...........verticillicerus Weele

1B. Antennae completely devoid of long setae

(Figs. 3, 4, 5) ................ 2
2A. Base of wings extremely narrow; hindwing with no apparent anal veins; forewing with CuP beyond axillary angle almost touching anal margin; costal margin clear

(Fig. 7) ............Ascaloptynx Banks

$2 B$. Base of wings not extremely narrow; hindwing with one apparent anal vein; in forewing CuP beyond axillary angle distant from anal margin; costal margin dark (Fig. 3) .........Neohaploglenius new g.

Genus Ascaloptynx Banks, 1915 (Fig. 7)

Neuroptynx of authors, nec. Neuroptynx McClendon. Ascaloptynx Banks, 1915. Ent. News, 26: 350.

Type Species: Ascalaphus appendiculatus Latreille, designated by Banks (1915).

This genus has extremely narrowed wings basally with a distinctive axillary angle in the forewing. Three species are known: A. appendiculatus, $A$. furciger and $A$. juvenilis. The geographical distribution is from Arizona to Texas to Florida to North Carolina, all within the United States. This genus is not commonly encountered.

\section{Genus Neohaploglenius new genus (Fig. 3)}

Type Species: Haploglenius flavicornis MacLachlan, by present designation.

Head: Antennae longer than distance to first fork of Rs, but shorter than distance to wing margin; without whorls of setae. Compound eyes entire; superior margin level with vertex. Wings: Costal margin dark, remainder of wing clear. Origin of Rs basal of CuA fork. M and CuA nearly straight. CuA fork distinct. In forewing axillary angle well developed, but CuP not touching wing margin. In hindwing one anal vein present.

Abdomen: Uniformly narrow, without dorsal structures or whorls of setal tufts.

This genus is being erected for two species of Haploglenius which do not appear very closely related to other members of the genus. 


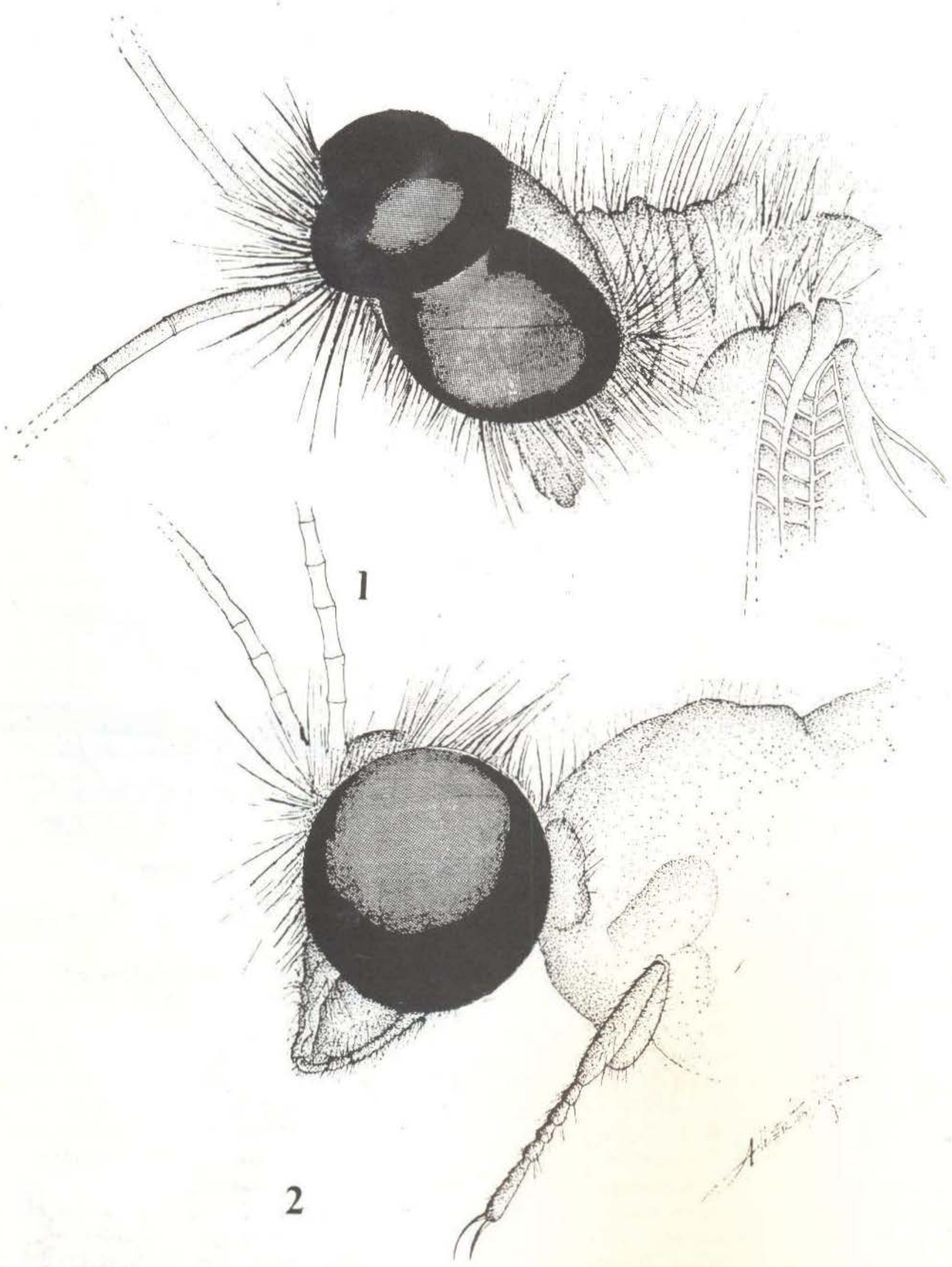

Figs. 1-2: 1) Lateral view of head of Cordulecerus elegans (Ascalaphinae); 2) Lateral view of head of Amoea iniquus (Walker) (Haplogleniinae). 


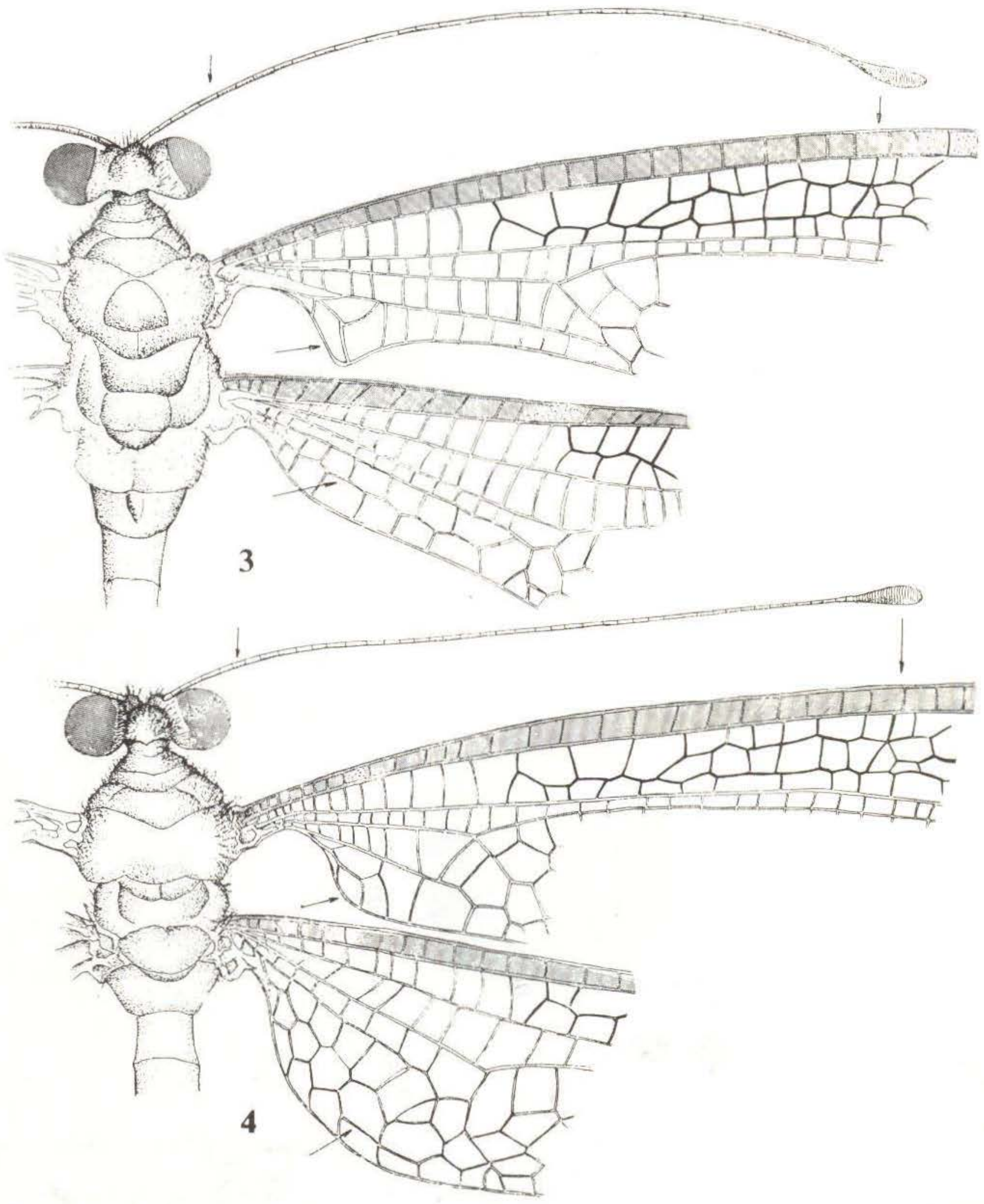

Figs. 3-4: 3) Base of right wings, head and antenna of Neo haploglenius (Verticillecerini), with $\mathrm{Sc}$ hidden behind R; 4) Base of right wings, head and antenna of Haploglenius costatus (Haplogleniini), with Ss hidden behind $R$. 
Especially distinct are the well-developed axillary angles of the forewing and lack of the second anal vein of the hindwing

The two included species are Neohaplogic. nius angulatus (Gerstaecker) and Neohaploglenius flavicornis (MacLachlan) with combined geographical distribution from Panama to $\mathrm{Me}$ xico.

\section{Genus Verticillecerus Weele, 1908}

(Fig. 6)

Verticillecerus Weele, 1808, Coll. zool. Edm, Selys Longchamps, 8: 54 .

Type Species: Verticillecerus gerstaeckeri Weele, by monotypy.

Verticillecerus is a distinctive genus of owlflies, with whorls of setae on the basal antennal joints, and darkened costal area. This is a monotypic genus, with only Verticillecerus gerstaeckeri Weele. This species is only known from Paraguay and Missiones Province, Argentina (Williner, 1945). Only five specimens of this genus have been mentioned in the Iiterature.

Subfamily ASCALAPHINAE Lefèbvre, 1842

Ascalaphidae Lefèbvre, 1842, Guerin's Mag. zool., 4: Table 92 .

Schizophthalmi Lefèbvre, 1842, Guerin's Mag. zool., 4: Table 92, (invalid, not based on valid genus name).

\section{Type Genus: Ascalaphus Fabricius}

This subfamily is easily characterized because it is the only subfamily with compound eyes divided by a median sulcus. Ascalaphinae is also the largest subfamily: Weele (1908) recorded seven tribes, 33 genera and 154 species worldwide. Only two tribes, Suhpalacsini and Ululodini, are found in the New World. A third tribe. Acmonotini, was mentioned by Weele (1908) but Navás (1919) pointed out the single species belonged in the Suhpalacsini. A fourth tribe. Hibrisini, was mentioned by $\mathrm{Na}$ vás (1913) based on a Chilean larva described by Brethes (1908). Stange (personal communication) states that this specimen is actually a myrmeleontid larva and Ascalaphidae do not exist in Chile. Penny (1977) recorded 77 species from South and Central America. In the New World, this subfamily ranges from Ar. gentina north to Connecticut and Illinois in the United States.

\section{KEY TO AMERICAN TRIBES OF ASCALAPHINAE}

1A. In hindwing, fork of CuA well-developed: CuP short and almost straight

(Fig. 8) ............ Suhpalacsini Weele

1B. In hindwing, fork of CuA absent; CuP long and usually arched

(Figs. 9, 10,11) ....... Ululodini Weele

Tribe SUHPALACSINI Weele, 1908

Suhpalacsini Weele, 1908, Coll. zool. Edm. Selys Longchamps, 8: 156.

Acmonotini Weele, 1908, Coll. zool. Edm. Selys Longchamps, 8: 198, synonomized by Navás (1919).

\section{Type Genus: Suhpalacsa Lefèbvre .}

This tribe has a well-developed fork of CuA of the hindwing, reminiscent of the Haplogleniinae. Suhpalacsini remains the least known and most confused tribe of American Ascalaphidae. When Weele (1908) wrote his monographic revision of Ascalaphidae, no members of this tribe were known from the New World, although one species of Acmonotini was mentioned from Argentina. Navás (1914) described the first species in his new genus Nephelasca from Colombia. In 1919, Navás described a second species of this tribe in another new genus, Fillus, from Argentina. In this same article he synonomized the tribes Suhpalacsini and Acmonotini, transferring the only American species of the latter tribe to his genus Fillus. In this same work, he included a key to known genera of Suhpalacsini, without mentioning his genus Nephelasca. In fact, this genus was not mentioned again until Penny's check-list of Latin American Neuropte$\mathrm{ra}$ in 1977. The original description is of a single female, and genera within the tribe are separated by characters of the male abdomen, so that exact placement of this genus is at 


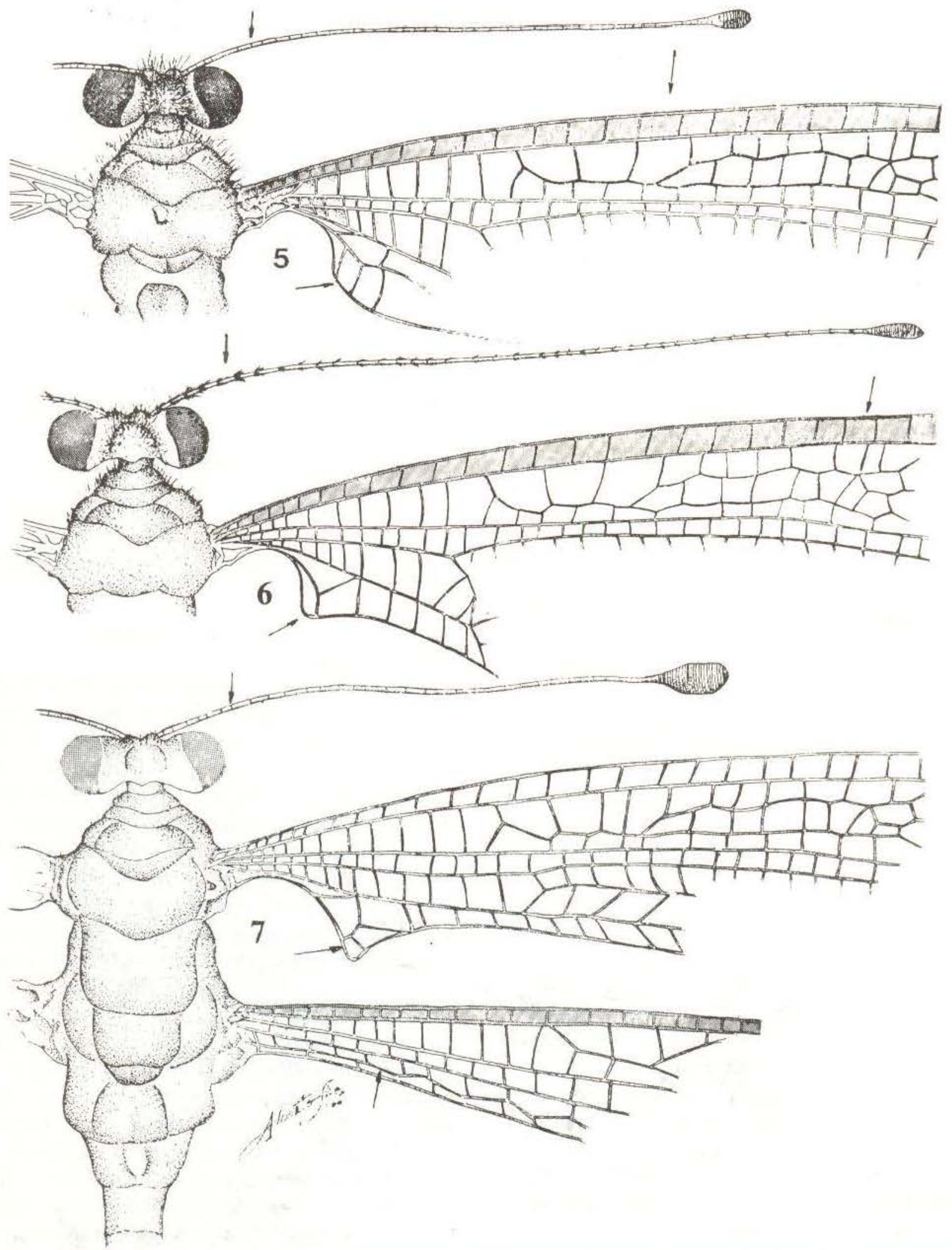

Figs. 5-7: 5) Base of right wings, head and antenna of Ascalobyas (Haplogleniini), with Sc hidden behind R; 6) Base of right wings, head and antenna of Verticillecerus (modified from Weele, 1908) (Verticillecerini) with Sc hidden behind $\mathrm{R} ;$ 7) Base of right wings, head and antenna of Ascaloptynx (adapted from Weele, 1908) (Verticillecerini) with Sc hidden behind R. 

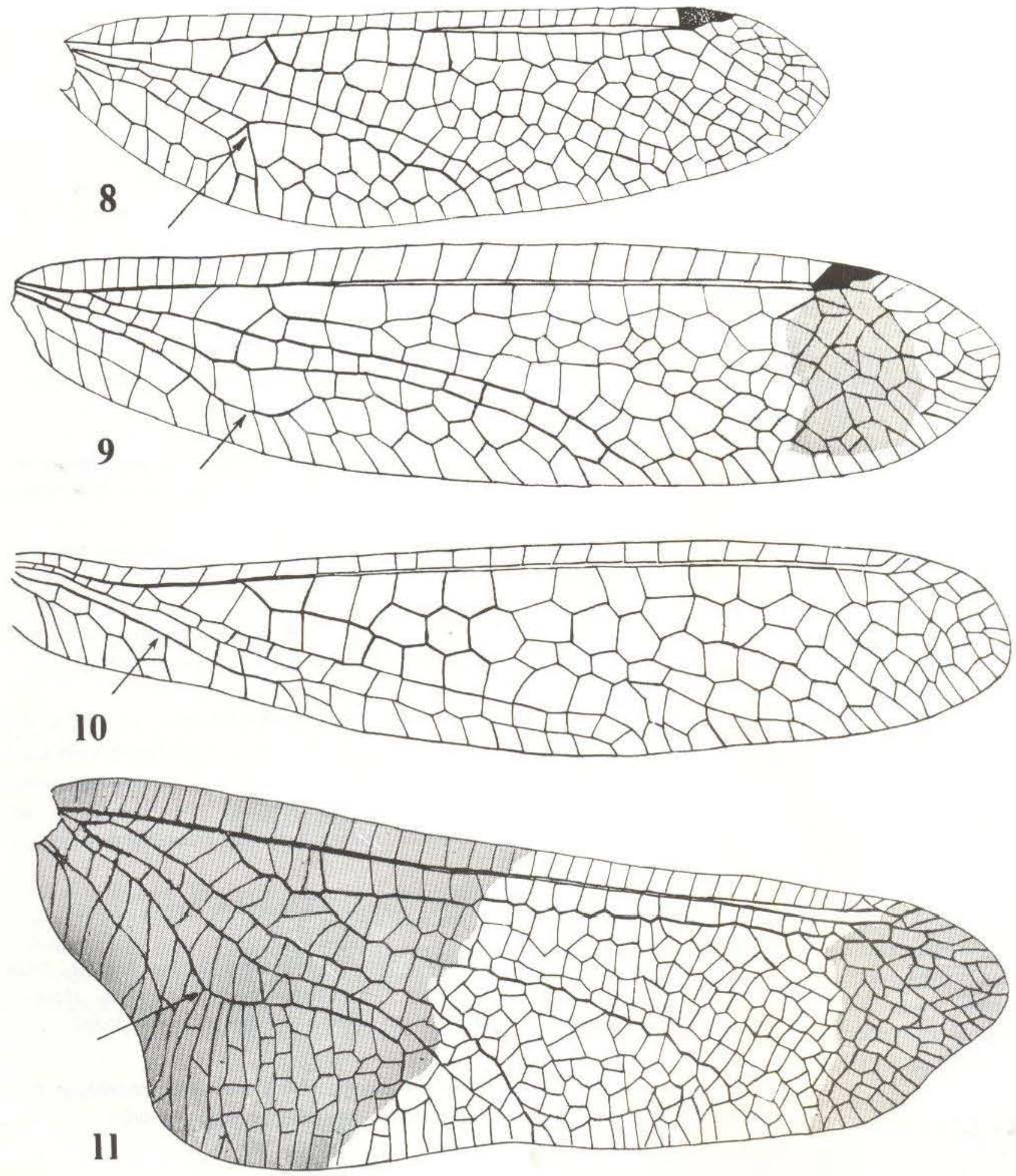

Fig. 8-11: 8) Hindwing of Fillus paradoxus (Weele) (adapted from Weele, 1908) (Suhpalacsini), with Sc partially hidden behind R; 9) Hindwing of Ululodes macleayana (Guilding) (Ululodini), with Sc partially hidden behind R; 10) Hindwing of Ameropterus delicatulus (MacLachlan) (Ululodini), with Sc partially hidden behind $\mathrm{R} ; 11$ ) Hindwing of Cordulecerus elegans Weele (Ululodini), with Sc partially hidden behind R. 
present not possible. Suhpalacsini is mostly confined to the Old World and Fillus remains the only American genus of this tribe clearly defined.

Genus Fillus Navás, 1919

(Fig. 8)

Fillus Navás, 1919, Revta. R. Acad. Cient. exact. fis. nat. Madr., 17: 289.

Type Species: Fillus brethesi Navás.

Weele (1908) described an American spceies of the tribe Acmonotini, Acmonotus paradoxus. Navás (1919) transferred this species to his new genus Fillus, within the Suhpalacsini, along with describing a new species, Fillus brethesi. These are the only two American species in the genus. Fillus paradoxus (Weele) is still known only from the female holotype, and could be the senior synonym of Fillus brethesi. The known geographical distribution of Fillus is Argentina and $\mathrm{Pa}$ raguay.

Tribe ULuLodinI Weele, 1908

Ululodini Weele, 1908, Coll. zool. Edm. Selys Longchamps, 8: 94 .

Type Genus: Ululodes Currie.

Ululodini, characterized by divided compound eyes and no development of the fork of CuA in the hindwing, is the largest tribe of American owlflies. In the present study, four genera are recognized from Argentina north to northern United States.

\section{KEY TO GENERA OF ULULODINI}

1A. Axillary angle of the forewing very distinct (Figs. 3, 6, 7); antennae longer than forewing ...........Ascalorphne Banks

1B. Forewing smoothly curved to base, without axillary angle (Figs. 4, 5); antennae as long as, or shorter than, forewing
2A. In hindwing, CuP straight

(Fig. 10) ............Ameropterus E.P.

2B. In hindwing, CuP clearly sinuous (Figs. 9, 11) ................ 3

3A. Hindwing long and narrow, approximately as wide at midlength as near wing base (Fig. 9) .............. Ululodes Currie

3B. Hindwing trianguloid, much wider at midlength than near wing base

(Fig. 11) .........Cordulecerus Rambur

Genus Ameropterus Esben-Petersen, 1922

(Fig. 10)

Colobopterus Rambur, 1842, Hist, nat, des Insectes Nèvroptéres, p. 360 . (preoccupied by Colobopterus Mulsant, 1842)

Ameropterus Esben-Petersen, 1922, Ann, Mag. Nat. Hist., 10: 621 ,

Type Species: Ascalaphus versicolor Burmeister, designated by Weele (1908).

Among the Ululodini, Ameropterus is easily recognized by the straight hindwing vein CuP. Penny (1977) listed 21 species in this genus from South and Central America. One additional species is known from North America.

Genus Ascalorphne Banks, 1915

Orphne Lefèbvre, 1842, Guerin's Mag. Zool., 4: Table

92, p. 7, (preoccupied by Orphne Huebner, 1825). Ascalorphne Banks, 1915, Ent. News, 26: 350.

Type Species: Ascalaphus macrocercus Burmeister, designated by Weele (1908)

This is the only genus of Ululodini with distinctive axillary angles of the forewing. In this respect, they resemble the Verticillecerini of Haplogleniinae. Ascalorphne is a small genus with restricted distribution. Only four species are known, ranging from Argentina to northern Brazil and Bolivia. 
Genus Cordulecerus Rambur, 1842

(Figs. 1, 11)

Cordulecerus Rambur, 1842, Hist. nat. des Insectes Nèvroptères, p. 359 .

Type Species: Cordulecerus maclachlani Selys, designated by Weele (1908) .

Cordulecerus is a distinctive genus because of the trianguloid hindwings. Hindwings of most species are pigmented. In Amazonia, species of this genus appear to be confined to forested areas, and are most frequently found in tree canopies. Dr. Dodge Engleman (personal communication) noted a large swarm of more than 40 individuals of both sexes of Cordulecerus elegans Weele congregated together at the tip of a tree branch at dusk, in central Amazonia. Ten species and one subspecies have been described, ranging from $\mathrm{Ar}$ gentina north to Mexico.

\section{Genus Ululodes Currie, 1899} (Fig. 9)

Ulula Rambur, 1842, Hist. nat, des Insectes Névroptères, p. 357 (preoccupied by Ulula Cuvier, 1817).

Ululodes Currie, 1899, Insects of New Jersey, p. 57.

Type Species: Ascalaphus macleayana Guilding.

Ululodes is a large genus, characterized by long, narrow wings; very little development of fcrewing axillary lobes; and CuP arched in the hindwing. Species of this genus are often collected at lights in open fields and cutover areas. Penny (1977) recorded 21 species and 4 subspecies from South and Central America. Another two species and four subspecies are known from North America. The genus ranges from Argentina north to northern United States.

\section{Ungrouped genera}

The generic names Neulatus Navás (1912) from Chile and Sodirus Navás (1912) from Ecuador have been applied to neuropterous larvae placed in the Ascalaphidae. The state of our knowledge of larval taxonomy does not yet allow us to make an accurate assessment as to the validity of these names.

\section{Sumário}

A classificaçāo dos taxas superiores de Ascalaphidae do Novo Mundo é modificado para refletir informaçōes novas, e muitas mudanças que foram propostas em vários artigos durante os últimos 70 anos. A tentativa foi feita para conservar o conceito tradicional, quando possivel. Chaves e descrições sinópticas sāo elaboradas para subfamilias, tribus e gêneros americanos. Uma sinonomia nova (Episperches Gerstaecker = Amoea Lefèbvre), um nome novo (Ascalobyas para Byas Rambur) e um gênero novo (Neohaploglenius) são propostos.

\section{REFERENCES}

BANKS, $N$.

1915 - Two new names in the Ascalaphidae. Ent. News, 26: 350 .

BLYTH,

1840 - In Cuvier, Anim. Kingd., p. 175.

BRETHES, J.

1908 - Descripcion de una larva de Glyptobasis ? de Chile. Revta. chil. Hist. nat., 12: 15-17.

BURMEISTER, $\mathrm{H}$.

1839 - Handbuch der Entomologie. Neuroptera, 2 (2): 757-1017. Berlin.

CURRIE, R.

1899 - Neuroptera. In, Smith Insects of New Jersey, Suppl.

ESBEN-PETERSEN, P.

1922 - New species of Neuroptera in the British Museum. Ann. Mag. Nat. Hist., 10: 617-621.

GERSTAECKER, A

1893 - Ueber neue und weniger gekannte Neuropteren aus der familie Megaloptera, Burm. Mitt. naturw. Ver. Neu-Vorpomm., 25: 93 173.

HUEBNER

1825 - Verz. bekannt. Schmett., 20: 314 .

LEFEBVRE, A.

1842 - Ascalaphne. Ascalaphus Fabricius. Guerin's Mag. Zool., 6: tab. xcii, 1-10.

MCCLENDON, J.F.

1906 - Notes on the true Neuroptera. 3. A catalogue of Texas Neuroptera. Ent. News, 17: 169-173.

MacLACHLAN, R,

1871 - An attempt towards a systematic classification of the family Ascalaphidae. Proc. Linn. Soc. Lond,, 11: 219-276. 
MacLEOD, E.G.

1970 - The Neuroptera of the Baltic Amber. I. As. calaphidae. Nymphidae and Psychopsidae Psyche, Camb., 77:

MOEHRING

1758 - Geslach. Vogel., p. 4, 49.

MORRIS

1837 - In Wood, Naturalist, 2 (9): 123.

MULSANT

1842 - Histoire naturelle Coléopt. France, p. 165.

NAVAS, L.

1912 - Sinopsis de los Ascaláfidos (Ins. Neur.). Arx. de I'Institut de Ciencias, 1 (3): 45-143.

1913 - Ascaláfidos (Ins. Neur.) sudamericanos. Broteria, 10: 203-233.

1914 - Neuropteros sudamericanos. Primera serie. Broteria, 12: 45-57, 215-235.

1919 - Algunos insectos Neurópteros de la Argentina. Tercera Serie. Revta. R. Acad. Cien. exact. fis. nat. Madr., 17: 287-305.

1928 - Insectos neotrópicos. 4: Serie. Revta, chil. Hist. nat., 32: 106-128.
NEWMAN, E.

1853 - Proposed division of Neuroptera into two classes. Zoologist, 11: 181-204.

ORFILA, R.N.

1949 - Notas críticas sobre Ascalaphidae. An. Soc. cient. argent., 148: 187-194.

PENNY, N.D.

1977 - Lista de Megaloptera, Neuroptera e Raphidioptera do México. América Central, Ilhas Caraibas e América do Sul. Acta Amazonica. Supl., 7 (4): 1-62.

RAMBUR, J.P.

1842 - Histoire naturelle des Insectes Névroptères. Paris. 534 p.

WEELE, H.W. van der

1908 - Ascalaphiden. Monographisch Bearbeitet. Coll. zool. Edm. Selys Longchamps. Fasc. VIII. 326 pp., 254 figs., 2 pls.

WILLINER, G.J.

1945 - Ascaláfidos argentinos (Neurópteros). Rvta. Soc. ent. Argent. 12 (5) : 425-437.

(Aceito para publicação em 22/07/80) 